\title{
Qualitative Assessment of Some Available Water Resources in Efon-Alaaye, Ekiti State Nigeria
}

\author{
ILORI, BA; ADEWUMI, JR; *LASISI, KH; AJIBADE, FO
}

Department of Civil Engineering, School of Engineering and Engineering Technology, Federal University of Technology, Akure, Nigeria

*Corresponding author Email; senserltd@gmail.com; otherauthor's email: bilori@yahoo.com; jradewumi@futa.edu.ng; senserltd@gmail.com; foajibade@futa.edu.ng;Tel: +2347032308193

\begin{abstract}
As water is a major life sustainer, hence its portability is of great importance in performing that role well. In this study, various water samples were collected within Efon-Alaaye for both physicochemical and bacteriological tests. A total of nine (9) water samples were taken for analysis with six (6) from various surface sources and three (3) from groundwater sources in the study area. The mean turbidity value, temperature, total dissolved solids (TDS) concentration, hardness and EC are $2.92 \mathrm{NTU}, 23^{\circ} \mathrm{C}, 447.8 \mathrm{mg} / \mathrm{l}, 48.1 \mathrm{mg} / \mathrm{l}$ and $138.4 \mu \mathrm{S} / \mathrm{cm}$ respectively. Manganese has mean value of $0.27 \mathrm{mg} / \mathrm{l}$. The concentration of both copper and zinc ranges from $0.07-0.13 \mathrm{mg} / \mathrm{l} \mathrm{and}$ $0.16-0.55 \mathrm{mg} / \mathrm{l}$ with an average value of $0.04 \mathrm{mg} / 1$ and $0.28 \mathrm{mg} / \mathrm{l}$ respectively. Water samples collected were also analyzed for total coliform bacteria and ranged from 1 to $4.6 / 100 \mathrm{ml}$ with an average value of 3.29 colony/100 ml. On the basis of findings, the physico-chemical analysis reveals that some of the water samples were above the WHO standards for parameters like turbidity and TDS while the bacteriological test reveals that seven (7) of the water samples considered met the WHO requirement of portability while the other two samples contain faecal contaminant as E.coli was discovered, though at reasonable rate.
\end{abstract}

\section{DOI: https://dx.doi.org/10.4314/jasem.v23i1.5}

Copyright: Copyright (C 2019 Ilori et al. This is an open access article distributed under the Creative Commons Attribution License (CCL), which permits unrestricted use, distribution, and reproduction in any medium, provided the original work is properly cited.

Dates: Received: 21 December 2018; Revised: 16 January 2019; Accepted 22 January 2019

Keywords: Physicochemical, Bacteriological, Groundwater, Surface water

Water, is an essential and necessary commodity regarded as life sustainer (Ele, 2013; Oyedum, 2016). It is impossible to survive without its availability. Water along with air, is one of the two most critical components for life, with shortage of water in our bodies, we cannot physically behave well and deprived of drinking water, we would die within three to seven days; as seventy percent of the human body is water (Cartwright, 2015). Water has been considered as a global heritage which everyone should have a non-negotiable social and political right to (Akali et al., 2014; Ajibade et al., 2015) but it is unfortunate that this precious commodity has been politically and socially influenced by several factors resulting in an uneven distribution of it. In fact, Babatola and Oguntuase (2008) and Ele (2013) put forward that the world is experiencing shortage of fresh water. Cartwright (2015) further affirm that, to say we are running out of water are either gross exaggerations or just plain wrong, but we are experiencing a growing shortage of fresh water. The world has numerous water from various sources (over 326 million cubic miles); however, $97 \%$ is seawater quality and of the $3 \%$ that is fresh water, almost $90 \%$ is either glaciers/ice caps, too deep in the earth to be readily accessible or in the Earth's atmosphere (Cartwright, 2015; Mueller et al., 2015). Water fit for human consumption is called drinking or portable water and such water are free from impurities, pathogenic organisms or other harmful elements which is without taste or odour, aesthetically appealing and socially acceptable and they can be used for various purposes without any risk of acquiring any water borne disease (Oyedum, 2010). The availability of a reliable and clean supply of water is one of the most important determinants of our health (Parson and Jefferson, 2006). According to WHO, diseases related to drinking-water contamination or pollution represent a major burden on human health and the interventions to improve the quality of drinking-water provide significant benefits to health (WHO, 2006). Water pollution has turned out to be a major problem in most developing countries of the world and this primarily occurs as a result of the indiscriminate disposal of untreated effluents and other wastes (Nair and Kani, 2017; Adewumi and Ajibade, 2015; Ajibade et al., 2014). People are left with no choice but to drink polluted water because they have no alternatives (Mukesh, 2012). Over 780 million people have been estimated 
lacking access to proper and improved sources of drinking water (Enyew and Tesfaye, 2017). Despite the fact that, there are numerous surface waters such as rivers, lakes, non-protected springs and ponds in developing countries, yet majority of these waters have been polluted resulting from poor behavioural living system. People living near water use it for washing clothes, bathing, animal watering and other domestic uses.

As water pollutants usually contain a wide range of pathogens, various biological wastes, different chemical substances, and so on (Nair and Kani, 2017), which constitute serious threat to public health, there is therefore need to take urgent actions by examining the physicochemical and microbiological properties of water samples obtained from a study area in southwestern, Nigeria. Failure of currently affected populations and relevant stakeholders all over the world to wake up to the consciousness of what I tag 'Water Redemption' which means the restoration of water back to a safer point for human consumption; water from these sources will continually be contaminated with feces, containing opportunistic organisms that are harmful to humans, which may finally cause severe illness and subsequently death (Oyedum et al., 2016). This study therefore aims at assessing the water quality of some available water resources in Efon-Alaaye and to suggest appropriate water treated mechanism.

\section{MATERIALS AND METHODS}

Description of the Study Area: Efon-Alaaye is located between latitude $7^{\circ} 6^{\prime} \mathrm{N}$ and $7^{\circ} 15^{\prime}$ North of the Equator and longitude $4^{\circ} 8^{\prime} \mathrm{E}$ and $4^{\circ} 52^{\prime}$ East. It is bounded round by chains of ridges rising to an average height of about 500 metres above the sea level. It is situated in a valley that spreads over an area of about 136 square meters (Oyedele, 2010). Efon-Alaaye is the gateway to Ekiti State from Ilesha (Osun State) and its affinity with Ekiti is more on the geographical location than its cultural traits. It falls within the humid tropical zone characterized by the wet and dry climate. It enjoys relatively heavy rainfall annually (March-October) which is characterized by thunder storms. Efon is drained by many streams and rivers from the surrounding hills. They are dependable even in dry season because they never dry up completely. Two of such rivers are historically significant for they are believed to be of medicinal value which the people consider as divine blessings bestowed on them. River Olua is believed to be capable of healing victims of guinea worm, while River Oni is also believed to possess elements of divine healing to the sick and capable of washing off misfortune in anybody who bathes in it after the
Late Apostle Joseph Ayo Babalola of Christ Apostolic Church (C.A.C.) blessed it. These two miraculous rivers attract people from diverse areas of Yoruba land to Efon - Alaaye (Adeoti, 2013).

Stream Flow Measurement and Sample Collection: Water sample was collected from two major water sources in the study area namely surface water and groundwater sources. Surface water samples were collected from six (6) rivers at a period of the year when the stream flow was almost steady while ground water samples were collected from three (3) sources within the study area making it a total of nine (9) water samples. The rivers by name are River Oni, River Afeni, River Orooro, River Babalola, ItaAwure River and River Olua while the ground water sources are Ojodi Borehole, Oniyo Borehole and ItaAwure Borehole. Figure 1 shows locations in the study area where water samples were collected. Before collection of the water sample from the rivers, the stream flow rate for each of the river was determine using the float methods. Samples were then collected into various containers and sealed with tight fitting cork and stoppers to prevent entrance of air. At the point of collection, both the temperature and $\mathrm{pH}$ values were determined using standardized thermometer graduated in tenths of degree centigrade and a digital hand-held $\mathrm{pH}$ meter (Hanna Instruments model). Samples were thereafter kept in a refrigerator at $4^{\circ} \mathrm{C}$ prior to analysis for preservation.

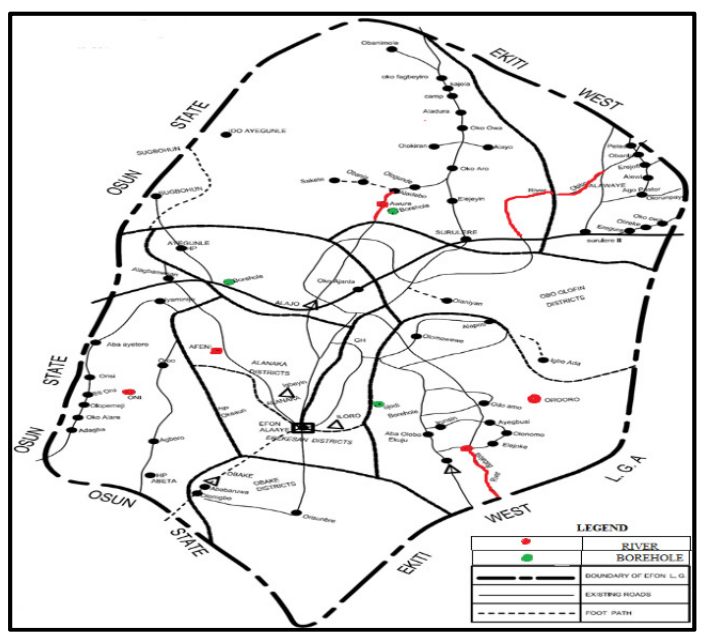

Fig 1: Characteristics Features Map of Efon-Alaaye Local Government showing the Streams and Borehole Locations where water samples were taken

Physicochemical and Bacteriological Test: In preparation for this test, all the apparatus used were sterilized. The samples collected were analyzed for $\mathrm{pH}$, total dissolved solid (TDS), total soluble solids (TSS), turbidity, electrical conductivity (EC), 
alkalinity, chloride content, hardness ( $\mathrm{Ca}$ and $\mathrm{Mg}$ ) and heavy metals. Standard guidelines provided by WHO (2006) were used in carrying out the analysis both at the Civil and Environmental Engineering Laboratory and the Microbiology Laboratory of the Federal University of Technology, Akure, Nigeria.

\section{RESULTS AND DISCUSSION}

Stream Flow Result: The stream flow measurement results for all the water sources are presented in Table 1. It can be observed that the flow rate depends on the depth and width of the river. River Ita-awure has the highest flow rate of $1.04 \mathrm{~m}^{3} / \mathrm{s}$ with depth and width of $1.3 \mathrm{~m}$ and $2.5 \mathrm{~m}$ respectively. It has a smooth/moldy streambed with high turbidity of 305 NTU due to scouring occurring at the stream banks of the water as it flows through the stream bank. River Babalola also possesses similar characteristics. River Babalola is linked by a lined drainage that conveys runoff from the town into the stream on the upstream side. This generates a sort of eddy which enhanced the absorption of oxygen and invariably increases the dissolved oxygen content of the stream. River Oni has its upper course lined, while the middle course is filled with protective vegetative cover. It has smooth/fine sand streambed, and it is characterized by free flowing clear water. River Afeni and River Orooro possess rocky/coarse streambed. Water movement in these rivers can be termed as gentle uniform flow, gradually flowing out of the rock cracks/faults. They are characterized by low depth and low turbidity owing to the type of flow. The stream bank of river Olua is bare and subject to water erosion. It is characterized by large width and shallow depth.

Physicochemical Properties of Water: Table 2 present the results of the physicochemical analysis conducted on the water samples from both surface and groundwater sources.

$\mathrm{pH}$ and Alkalinity of Water: $\mathrm{pH}$ is an important parameter used to evaluate the acid-base balance of water. It is also the indicator of acidic or alkaline condition of water status. WHO has recommended maximum permissible limit of $\mathrm{pH}$ from 6.5 to 8.5 . The current investigation ranges from 6.5 to 7.2 which are in the range of WHO standards. The alkalinity from Table 2 shows that Ita-Awure borehole water sample has the highest alkalinity value of $424 \mathrm{mg} / \mathrm{l}$ making the water unsafe for drinking as it exceed the WHO permissible limit of 20-200 mg/l for typical drinking water.

Temperature: For the temperature analysis, cool or cold water is generally more palatable than warm water as water with high temperature enhances micro-organisms growth and usually increases taste, odour, and colour. For this study, temperature value ranged between $21^{\circ} \mathrm{C}$ and $24^{\circ} \mathrm{C}$. Therefore, they were found within permissible limit of WHO standard (i.e. $30{ }^{\circ} \mathrm{C}$ ). Ezeribe et al. (2012) reports similar result for some groundwater water in some villages in Nigeria.

Total Dissolved Solid (TDS): Water with high TDS value indicates that water is highly mineralized as water has the ability to dissolve a wide range of inorganic and some organic minerals or salts such as potassium, calcium, sodium, bicarbonates, chlorides, magnesium, sulfates etc. The desirable limit for TDS is $500 \mathrm{mg} / \mathrm{l}$ and maximum limit is $1000 \mathrm{mg} / \mathrm{l}$ which prescribed for drinking purpose. The concentration of TDS obtained in Table 2 shows that the TDS level all fall below the WHO limits with exception of Ojodi borehole with significant high TDS values of 1,240 $\mathrm{mg} / \mathrm{l}$. Though, river Afeni, and Ita-Awure borehole has moderately high TDS values of $650 \mathrm{mg} / \mathrm{l}$ and 770 $\mathrm{mg} / \mathrm{l}$ respectively, they are still within the limit of WHO standards. High values of TDS in groundwater are generally not harmful to human beings, but high concentration of these may affect persons who are suffering from kidney and heart diseases. Water containing high solid may cause laxative or constipation effects according to Sasikaran et al. (2012).

Electrical Conductivity: Pure water is not a good conductor of electric current but a good insulator. Increase in ions concentration enhances the electrical conductivity of water. Generally, the amount of dissolved solids in water determines the electrical conductivity. Electrical conductivity (EC) actually measures the ionic process of a solution that enables it to transmit current (Meride and Ayenew, 2016). According to WHO standard, EC value should not exceeded $400 \mu \mathrm{S} / \mathrm{cm}$. From Table 2, all the samples analyzed have EC values lower than the WHO recommended value except Ojodi borehole having EC value of $414 \mu \mathrm{S} / \mathrm{cm}$, a value higher than the recommended value. These results clearly show that, all the water in the study area except the Ojodi borehole ware not considerably ionized and have lower level of ionic concentration activity due to small dissolve solids present in them.

Turbidity: The turbidity of water depends on the quantity of solid matter present in the suspended state. It is a measure of light emitting properties of water and the test is used to indicate the quality of waste discharge with respect to colloidal matter (Meride and Ayenew, 2016). Table 2 shows that two of the rivers have high turbidity with values above the 
WHO permissible standard. The two water sources are river Orooro and river Ita-Awure with turbidity values of 6.10 NTU and 5.65 NTU respectively. These values are due to the high quantity of solid matter present in the rivers.

Hardness: Hardness contributed by calcium and magnesium, bicarbonate and carbonate mineral species in water is called carbonate hardness; hardness in excess of this concentration is called noncarbonate hardness. Water that has a hardness less than $61 \mathrm{mg} / \mathrm{l}$ is considered soft; 61-120 mg/l, moderately hard; $121-180 \mathrm{mg} / \mathrm{l}$, hard; and more than $180 \mathrm{mg} / \mathrm{l}$, very hard (Heath, 1983). The hardness values of the water sources in Table 2 ranges from 16 $\mathrm{mg} / \mathrm{l}$ to $136 \mathrm{mg} / \mathrm{l}$ which falls within the WHO permissible limits.
Chlorides $(\mathrm{Cl})$ : Chloride is mainly obtained from the dissolution of salts of hydrochloric acid as table salt $(\mathrm{NaCl})$. It has key importance for metabolism activity in human body and other main physiological processes. Surface water bodies often have low concentration of chlorides as compare to ground water. High chloride concentration damages metallic pipes and structure, as well as harms growing plants. According to WHO standards, concentration of chloride should not exceed $250 \mathrm{mg} / \mathrm{l}$. In the study areas, all water sources fall within the WHO limit except for Ojodi and Ita-Awure boreholes which possess higher chloride concentration of $260 \mathrm{mg} / \mathrm{l}$ and $310 \mathrm{mg} / \mathrm{l}$ respectively above the WHO's standard.

Table 1: Streamflow results for all the surface water sources in the study area

\begin{tabular}{lccccccccc}
\hline $\begin{array}{l}\text { Rivers } \\
\text { (Surface }\end{array}$ & $\begin{array}{c}\mathbf{L} \\
(\mathbf{m})\end{array}$ & $\begin{array}{c}\mathbf{B} \\
(\mathbf{m})\end{array}$ & $\begin{array}{c}\mathbf{D} \\
(\mathbf{m})\end{array}$ & $\begin{array}{c}\mathbf{t} \\
(\mathbf{s})\end{array}$ & $* \mathbf{n}$ & $\begin{array}{c}\mathbf{A} \\
\left(\mathbf{m}^{2}\right)\end{array}$ & $\begin{array}{c}\mathbf{V} \\
(\mathbf{m} / \mathbf{s})\end{array}$ & $\begin{array}{c}\text { Adj. } \\
\mathbf{V}(\mathbf{V} \\
\times \mathbf{n})\end{array}$ & $\begin{array}{c}\text { Streamflow } \\
\left(\mathbf{m}^{\mathbf{3}} / \mathbf{s}\right)\end{array}$ \\
\hline Oni & 2.0 & 2.4 & 0.8 & 0.4 & 0.09 & 1.92 & 5.00 & 0.450 & 0.864 \\
Afeni & 2.0 & 2.0 & 0.4 & 1.2 & 0.09 & 0.80 & 1.67 & 0.150 & 0.120 \\
Orooro & 2.0 & 2.1 & 0.6 & 1.4 & 0.08 & 1.26 & 1.43 & 0.114 & 0.144 \\
Babalola & 2.0 & 2.1 & 1.2 & 0.6 & 0.08 & 1.47 & 2.86 & 0.230 & 0.338 \\
Ita- & 2.0 & 2.5 & 1.3 & 0.5 & 0.08 & 3.25 & 4.00 & 0.320 & 1.040 \\
awure & & & & & & & & & \\
Olua & 2.0 & 3.1 & 0.4 & 1.0 & 0.09 & 1.24 & 2.00 & 0.180 & 0.223 \\
\hline
\end{tabular}

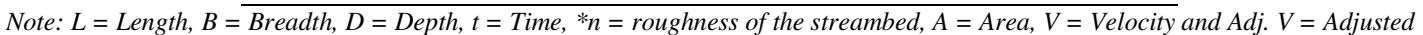
Velocity

Table 2: Physico-chemical analysis of selected surface and ground water in the study area

\begin{tabular}{|c|c|c|c|c|c|c|c|c|c|c|}
\hline Parameters & $\mathbf{A}$ & B & $\mathrm{C}$ & D & $\mathbf{E}$ & $\mathbf{F}$ & G & $\mathbf{H}$ & I & WHO Limit \\
\hline$\overline{\mathrm{pH}}$ & 6.5 & 6.6 & 6.8 & 7.1 & 7.2 & 6.7 & 6.7 & 6.9 & 7.2 & $6.5-8.5$ \\
\hline Temperature $\left({ }^{\circ} \mathrm{C}\right)$ & 23.0 & 24.0 & 24.0 & 23.5 & 23.0 & 23.5 & 21.0 & 23.0 & 22.0 & 30 \\
\hline $\mathrm{TDS}(\mathrm{mg} / \mathrm{l})$ & 110 & 650 & 120 & 250 & 430 & 270 & 1240 & 190 & 770 & $500-1000$ \\
\hline Turbidity (NTU) & 4.33 & 0.62 & 6.10 & 3.57 & 5.65 & 3.75 & 0.94 & 0.62 & 0.71 & 5.00 \\
\hline Conductivity $(\mu \mathrm{S} / \mathrm{cm})$ & 42.0 & 224.0 & 22.0 & 52.0 & 88.0 & 56.0 & 414.0 & 38.0 & 310.0 & 400 \\
\hline Alkalinity (mg/l) & 36 & 24 & 28 & 44 & 92 & 48 & 108 & 28 & 424 & $20-200$ \\
\hline Hardness (mg/l) & 26 & 33 & 36 & 16 & 33 & 28 & 78 & 47 & 136 & $100-200$ \\
\hline Chloride content $(\mathrm{mg} / \mathrm{l})$ & 60 & 20 & 70 & 60 & 46 & 57 & 260 & 50 & 310 & 250 \\
\hline
\end{tabular}

Note: ${ }^{*}$ N/A = not available, $A$ is River Oni, B is River Afeni, $C$ is River Orooro, $D$ is River Babalola, E is River Ita-Awure, $F$ is River Olua, $G$ is Ojodi Borehole, $H$ is Oniyo borehole and I is Ita-Awure borehole.

Table 3: Heavy Metals in selected surface and ground water in the study area

\begin{tabular}{lcccccccccc}
\hline Parameters & A & B & C & D & E & F & G & H & I & WHO Limits \\
\hline Manganese $(\mathrm{Mn})$ & 1.72 & 0.11 & 0.23 & 0.10 & ND & ND & ND & ND & 0.32 & 0.4 \\
Iron $(\mathrm{Fe})$ & 1.84 & 0.92 & 0.54 & 1.10 & 1.26 & 1.01 & 0.20 & 0.21 & 0.10 & 0.3 \\
Copper $(\mathrm{Cu})$ & 0.09 & 0.13 & 0.04 & 0.03 & 0.01 & 0.02 & 0.02 & 0.02 & 0.03 & 2.0 \\
Zinc $(\mathrm{Zn})$ & 0.47 & 0.55 & 0.19 & 0.23 & 0.22 & 0.19 & 0.22 & 0.25 & 0.16 & $3-5$ \\
Lead $(\mathrm{Pb})$ & ND & ND & ND & ND & ND & ND & ND & ND & ND & 0.1 \\
\hline
\end{tabular}

Note: $A$ is river Oni, $B$ is river Afeni, $C$ is river Orooro, $D$ is river Babalola, $E$ is river Ita-Awure, $F$ is river Olua, $G$ is Ojodi borehole, $H$ is Oniyo borehole and I is Ita-Awure borehole (ND means Not Detected)

Table 4: Variation of Microbial Loads of Major Water Bodies in Efon-Alaaye

\begin{tabular}{lcccccccccc}
\hline $\begin{array}{l}\text { Parameters } \\
\text { (cfu/100ml) }\end{array}$ & A & B & C & D & E & F & G & H & I & $\begin{array}{l}\text { WHO } \\
\text { Limits }\end{array}$ \\
\hline Total Viable Counts & 4.6 & 5.3 & 1.8 & 5.6 & 5.2 & 4.8 & 3.7 & 1.4 & 4.2 & $*$ N/A \\
Total Coliform Counts & 3.4 & 4.5 & 1.2 & 4.2 & 4.6 & 4.1 & 3.2 & 1.0 & 3.4 & 10.0 \\
E.Coli (Faecal Coliform & 0.0 & 1.0 & 0.0 & 0.0 & 0.0 & 1.2 & 0.0 & 0.0 & 0.0 & 0.0 \\
$\begin{array}{l}\text { Counts) } \\
\text { Fungi Counts }\end{array}$ & 3.2 & 4.5 & 1.3 & 4.8 & 4.0 & 3.5 & 2.4 & 1.0 & 2.7 & $*$ N/A \\
\hline
\end{tabular}

*N/A means Not available; Note: $A$ is river Oni, $B$ is river Afeni, $C$ is river Orooro, $D$ is river Babalola, $E$ is river Ita-Awure, $F$ is river Olua, $G$ is Ojodi borehole, $H$ is Oniyo borehole and I is Ita-Awure borehole (ND means Not Detected) 
Heavy Metals: Table 3 presents the heavy metals present in all the water samples collected. It was observed that river Oni has a heavy concentration of manganese ion $(1.72 \mathrm{mg} / \mathrm{l})$. Manganese were not detected in river Ita-Awure, river Olua, Ojodi borehole and Oniyo Borehole while river Afeni, river Orooro, river Babalola and Ita-Awure borehole all fall within an acceptable tolerance limit of $0.4 \mathrm{mg} / \mathrm{l}$. Thus appropriate treatment is required before consumption while for Iron (Fe), all water sources examined has a significant proportion of iron content, ranging from $0.10 \mathrm{mg} / \mathrm{l}$ to $1.84 \mathrm{mg} / \mathrm{l}$, higher than the WHO stipulated maximum limit of $0.3 \mathrm{mg} / \mathrm{l}$. This is largely due to the geological properties of the area and the mineralogy of the streambed and bank through which water flows. The concentration of Copper $(\mathrm{Cu})$ in the water sources ranges from 0.01 $\mathrm{mg} / \mathrm{l}$ to $0.13 \mathrm{mg} / \mathrm{l}$. These values fall relatively below the maximum tolerable limit of $2.0 \mathrm{mg} / \mathrm{l}$. Water samples analyzed are free of Zinc ( $\mathrm{Zn}$ ) concentration as the measured value, ranges from $0.16 \mathrm{mg} / \mathrm{l}$ and $0.55 \mathrm{mg} / \mathrm{l}$, which were far less when compared to the maximum permissible limit of 3 to $5 \mathrm{mg} / \mathrm{l}$. No Lead $(\mathrm{Pb})$ concentration was detected in any of the water sources analyzed.

Microbiological Results Analysis: For the microbiological analysis, the total coliform group has been selected as the primary indicator bacteria for the presence of disease causing organisms in water (especially in drinking water). It is a primary indicator of suitability of water for consumption. If large numbers of coliforms are found in water, there is a high probability that other pathogenic bacteria or organisms exist. The WHO drinking water guidelines require the absence of total coliform in drinking water supplies especially public ones. In this study, some faecal coliform bacteria were detected in some of the water sources analyzed. From Table 4, the total coliform bacteria ranged from 1.0 to $4.6 / 100 \mathrm{ml}$ which falls within WHO (2006) maximum tolerable limit of 10 count/100 ml. According to WHO (2011) risk associated in Efon-Alaaye drinking water is low risk (1-10 count/100 ml). The presence of $E$. coli in Table 4 shows evidence of faecal contamination. The three boreholes examined shows absence of $E$. coli while out of the six (6) rivers considered, two rivers (river Afeni and Olua) have faecal coliform count of $1.0 \mathrm{cfu} / 100 \mathrm{ml}$ and $1.2 \mathrm{cfu} / 100 \mathrm{ml}$ respectively This result implies that water samples from river Afeni and Olua require some level of treatment to remove $E$. coli before using for domestic consumption.

Conclusion: In this study, the collected water samples from various sources in Efon-Alaaye local government area were analyzed for physico-chemical and bacteriological parameters. On the basis of findings, it can be concluded that most of water samples analyzed for physic-chemical properties of the study areas were consistent with World Health Organization standard for drinking water (WHO). It is evident that most of all the water samples with heavy metals analyzed also fall under the permissible limit thus representing no toxicity problem for such. There are few exceptions which occur in some of the water samples as they have values higher than the WHO permissible values. Some are river Orooro and Ita-Awure in the case of turbidity, Ojodi borehole in the case of TDS and Ita-Awure borehole in the case of alkalinity and chloride content. Also, the bacteriological determination of water samples from the study area was carried out to be sure if the water were safe for consumption.

Acknowledgements: The authors acknowledge the Department of Microbiology and also Civil Engineering Department of the Federal University of Technology Akure for supporting us with necessary apparatus and equipment during the analysis.

\section{REFERENCES}

Adewumi, JR; Ajibade, FO (2015). The Pollution Effect of Indiscriminate Disposal of Wastewater on Soil in Semi-Urban Area. J. Appl Sci Environ. Manage. 19 (3): 412 - 419.

Ajibade, FO; Adewumi, JR; Oguntuase, AM (2014). Sustainable Approach to Wastewater Management in the Federal University of Technology, Akure, Nigeria. Nig. J. Tech. Research, 9(2): 27-36.

Ajibade, FO; Adewumi, JR; Ojo, OM; Babatola, JO; Oguntuase, AM (2015). Issues, Challenges and Management of Water Supply and Sanitation in Nigeria: An Overview. 2015 Conference Proceedings on National Development Strategies towards Sustainable Civil Infrastructure, Nigerian Institution of Civil Engineers (www.nice-nigeria.org). Pp $19-34$.

Akali, DM; Iorhemen, OT; Otun, JA; Alfa, MI (2014). Provision of Sustainable Water Supply System in Nigeria: A Case Study of WannuneBenue State. World J. Environ Eng, 2(1): 1-5. doi: 10.12691/wjee-2-1-1.

Babatola, JO; Oguntuase, AM (2008). Technical and Socio Economic Appraisal Supply Situation in a Typical Nigerian Centre. Nig. J. Eng. 14(2): $72-$ 78. 
Cartwright, PS (2015). A Look at the Present and Into the Future of Potable Water Treatment. Water Conditioning and Purification Magazine. July 2015 Magazine Issue 2. Pp 4.

Ele, S (2013). Challenges of Water Supply in Nigeria since 1999 and its Consequences on Economic Development. Intl J. Eco. Dev. Research Invest, 4(3), 34-43.

Enyew, AZ; Tesfaye, BB (2017). Clay Ceramic Filter for Water Treatment. Materials Sci. Appl. Chem. 34: 69 - 74 .

Ezeribe, AI; Oshieke, KC; Jauro, A (2012). Physicochemical properties of well water samples from some villages in Nigeria with cases of stained and mottle teeth. Sci World J. 7(1):1-13.

Meride, Y; Ayenew, B (2016). Drinking water quality assessment and its effects on residents' health in Wondo genet campus, Ethiopia, Environ Syst Res, 5:1-7, DOI 10.1186/s40068-016-0053-6

Mueller, SA; BertBras, AC; Niemann, TA; Rokosz, SM; McKenzie, HL; Kim, HC; Wallington, TJ (2015). Requirements for water assessment tools: An automotive industry perspective. Wat. Res. Ind. 9: 30-44.

Mukesh, G; (2012). Water Pollution in India: Causes and Remedies. Intl. J. Phys. and Social Sci. 2(6): 555 - 567.
Nair, CS; Kani, KM (2017). Evaluating the Performance of Locally Made Ceramic Filters for Household Water Treatment. Intl. J. Research Technol. Studies. 4(6), pp. 40 - 45.

Oyedum, MU (2010). Occurrence of faecal coliform contamination of well and borehole water. An unpublished project thesis presented to the Department of Microbiology, Federal University of Technology Minna, Niger State. Pp 6.

Oyedum, UM; Adabara, NU, Oloruntimilehin, BJ (2016). A Survey of Bacteriological Quality of Well Water from Various Locations in Bosso Town, North Central, Nigeria, FUTA J. Research Sci. 12(2): $280-286$.

Parsons, SA; Jefferson, B (2006). Introduction to potable water treatment processes, Wiley Blackwell Publishing Ltd, Oxford, Pp 179.

Sasikaran, S; Sritharan, K; Balakumar, S; Arasaratnam, V (2012) Physical, Chemical and Microbial Analysis of Bottled Drinking Water. $J$ Ceylon Medical, 57(3):111-116.

World Health Organization (WHO) (2006). Guidelines for Drinking-water Quality, First Addendum to Third Edition, Volume 1 Recommendations, World Health Organisation, Geneva. Switzerland

World Health Organization (WHO) (2011). Guidelines for drinking-water quality, 4th Edition. World Health Organisation. Geneva Switzerland. 